\title{
BIOREMEDIATION OF WASTEWATER FOR REUTILIZATION IN AGRICULTURAL SYSTEMS: A REVIEW
}

\author{
MORA-RAVELO, S. G. ${ }^{1 *}$-ALARCÓN, A. ${ }^{2}$ - ROCANDIO-RODRÍGUEZ, M. ${ }^{1}{ }^{-}$ \\ VANOYE-ELIGIO, V. \\ ${ }^{1}$ Instituto de Ecología Aplicada, Universidad Autónoma de Tamaulipas. Av. División del Golfo \\ 356, Col. Libertad, Cd. Victoria 87019, Tamaulipas, México \\ ${ }^{2}$ Área de Microbiología. Posgrado de Edafología. Colegio de Postgraduados. Carretera México \\ Texcoco, km 36.5 Montecillo 56230, Edo. de México, México \\ *Corresponding author \\ e-mail:sgmora@uat.edu.mx
}

(Received 21 $1^{\text {st }}$ Apr 2016; Accepted $17^{\text {th }}$ Sep 2016)

\begin{abstract}
The bioremediation is a technique used in descontamination water, soil, o sludge, which consist of the use of living microorganisms and plant for degradation of pollutants by metabolic processes. Wastewater is often used in agriculture due to the limited availability of water resource, but also because wastewater provides nutrients for crops, and reduces cost production for some agricultural regions. However, its reuse as a source of irrigation in agriculture must first involve the use of bioremediation techniques. Until 2012, in Mexico, treated municipal wastewater accounted for about 50\% of all wastewater generated. This suggests that greater efforts are needed to generate efficient alternatives to increase the volume of treated wastewater, and thus meet the demand for this resource in the agricultural sector. This review discusses in general the use and reuse of treated wastewater through bioremediation techniques. The objetive of this research is to review the state of the art bioremediation and wastewater reuse for agriculture in Mexico.
\end{abstract}

Keywords: pollution, irrigation, phytoremediation, agroenvironment, agroecology

\section{Introduction}

A major problem at the global and national levels is related to the demand and quality of irrigation water (Sierra, 2011; Rulkens, 2008). This creates conflicts because, on one hand, there is little availability of drinking water and, on the other, mismanagement of wastewater leads to economic, social and environmental problems (Monroy, 2013; Peña, 2013). In Mexico, between 1998 and 2007, the generation of wastewater from urban centers (municipal) increased from 239 to $243 \mathrm{~m}^{3} \mathrm{~s}^{-1}$, while industrial (non-municipal) discharges increased from 170 to $188.7 \mathrm{~m}^{3} \mathrm{~s}^{-1}$ in the same period. Of the total volume of wastewater generated in those years, only $25.3 \%$ was treated (INEGI, 2012). Seventy-seven percent of all water is used in agriculture, but $15 \%$ of all aquifers are already overexploited; thus, there is the need for substituting first use water with treated wastewater in this sector (Mejía et al., 2013).

Crop irrigation with wastewater can bring economic benefits by taking advantage of their contents of $\mathrm{N}$ and $\mathrm{P}$, providing a supply of nutrients for plants and minimize the use of fertilizers, and supporting local food production (Plevich et al., 2012). In Mexico, in the Valle del Mezquital (Hidalgo), the volume of wastewater used for irrigation annually is between 10000 and $20000 \mathrm{~m}^{3} \mathrm{ha}^{-1}$, with concentrations of 20 to $40 \mathrm{mg} \mathrm{N} \mathrm{L}^{-1}$; thus, irrigation with this water is equivalent to apply doses of $200-800 \mathrm{~kg} \mathrm{~N} \mathrm{ha}^{-1}$ year $^{-1}$. In many cases, these amounts can cover the needs for $\mathrm{N}$ of some crops (Ramos, 1998). 
Two decades ago, the same dose of $\mathrm{N}$ represented an investment of between $\$ 335.00$ to $\$ 1340.00 \mathrm{~kg} \mathrm{~N} \mathrm{ha}^{-1}$ in the Valle del Mezquital (Hernández et al., 1993).

However, it is important to be cautious because wastewater not only contains nutrients, but also biological and chemical contaminants, such as heavy metals (Siebe, 1994; Méndez-García, 2000; Olmos and Alarcón-Herrera, 2014), which can damage human health (Rivera-Vázquez et al., 2007; Hernández-Acosta et al., 2014). According to the official standards established by SEMARNAT, the use of wastewater is defined in accordance to the sector or infrastructure that benefits from it; for example, urban use (irrigation of green areas, golf courses). However, the use of wastewater in agriculture depends on the type of treatment to which wastewater is subjected for use in irrigation of certain crops (Table 1). Westcot and Ayers (1984) indicate some fundamental criteria that urban wastewater must meet to be used in irrigation of agricultural and green areas (Table 2).

Table 1. Criteria for the use of wastewater in Mexico (Pescod, 1992).

\begin{tabular}{ll}
\hline Treatment & Vegetation type \\
\hline \multirow{2}{*}{ Storage and retention for a few months } & Not suitable for irrigation of crops that are eaten \\
& raw \\
Secondary & Suitable for irrigation of public parks \\
& Suitable for use in green areas along roads
\end{tabular}

Like other countries, Mexico has implemented programs for wastewater treatment since 2008, such as PROTAR (wastewater treatment program) and others, which seek to increase the volume of treated water and to improve the processes used for wastewater treatment. Under these projects, 2287 treatment plants were built throughout the country until December 2013 (CONAGUA, 2014); they operate according to the regulations of the General Law of National Waters (Atlas Digital del Agua, 2012). The quality of treated water must meet a series of physical, chemical and biological requirements. To this purpose, wastewater treatment involves a series of steps for recovering contaminated water its reuse. The disposal such treated water has effects on soil and on water bodies because wastewater treatment removes some contaminants, but not all, and many of them are toxic, such as heavy metals, which can be incorporated into the food web, causing direct or indirect damages to human health (Cañizares-Villanueva, 2000; Corinne et al., 2006; Rooney et al., 2006). For this reason, new alternatives for wastewater treatment have been developed, seeking to increase its reuse potential through different remediation techniques (CONAGUA, 2011, 2013a; Ferrera-Cerrato et al., 2006; Van Hamme et al., 2003).

Bioremediation refers to the optimization of naturally occurring remediation processes carried out by living organisms that degrade, alter or remove toxic organic compounds (Van Hamme et al., 2003). This biological strategy depends on the catabolic activities of organisms and on their ability to contribute to the degradation of contaminants of organic origin when using them as a source of food and energy (PilonSmits., 2005).The application of bioremediation techniques is an alternative for the disposal of non-treated wastewater during crop irrigation; the efficiency of bioremediation techniques depends on a number of factors that should be considered when choosing a treatment that provides the water quality that meets the needs of crops. 
First, one should consider the properties of the contaminants, since these define its potential for biodegradation, as well as the side effects that may affect the places from which contaminants have to be removed (Vassilev et al., 2004).

Table 2. Requirements that treated urban wastewater must meet for use in irrigation of agricultural and green areas.

\begin{tabular}{|c|c|c|c|}
\hline Water quality & $\begin{array}{l}\text { Type of crop or area } \\
\text { to be irrigated }\end{array}$ & $\begin{array}{l}\text { Irrigation method that } \\
\text { can be used }\end{array}$ & $\begin{array}{l}\text { Other conditions that } \\
\text { must be met }\end{array}$ \\
\hline $\begin{array}{l}\text { Number of intestinal } \\
\text { nematodes }(*):<1 \mathrm{~L}^{-1} \\
\text { Number of fecal } \\
\text { coliforms: }<200 / 100 \mathrm{~mL}^{-1}\end{array}$ & $\begin{array}{l}\text { Irrigation of sports } \\
\text { fields and green areas } \\
\text { open to the public }\end{array}$ & Any & $\begin{array}{l}\text { Irrigation should not } \\
\text { be performed during } \\
\text { public attendance } \\
\text { hours }\end{array}$ \\
\hline $\begin{array}{l}\text { Number of intestinal } \\
\text { nematodes }(*):<1 \mathrm{~L}^{-1} \\
\text { Number of fecal } \\
\text { coliforms: }<1000 / 100 \mathrm{~mL}^{-} \\
1\end{array}$ & $\begin{array}{l}\text { Irrigation of crops that } \\
\text { are eaten raw }\end{array}$ & Any & \\
\hline $\begin{array}{l}\text { Number of intestinal } \\
\text { nematodes }(*):<1 \mathrm{~L}^{-1}\end{array}$ & $\begin{array}{l}\text { Irrigation of } \\
\text { industrial, timber, } \\
\text { fodder, cereal and } \\
\text { oilseed crops, plant } \\
\text { nurseries, crops for } \\
\text { canning, plant } \\
\text { products that are } \\
\text { consumed cooked, } \\
\text { and fruit trees }\end{array}$ & $\begin{array}{l}\text { Any except: } \\
\text { Spraying and flooding } \\
\text { to irrigate vegetables } \\
\text { Spraying to irrigate } \\
\text { fruit trees }\end{array}$ & $\begin{array}{l}\text { The irrigation of fruit } \\
\text { trees with this type } \\
\text { water should be } \\
\text { suspended at least two } \\
\text { weeks before harvest, } \\
\text { and the fruit should } \\
\text { not be collected from } \\
\text { the ground } \\
\text { The irrigation of grass } \\
\text { for green fodder must } \\
\text { be suspended at least } \\
\text { two weeks before the } \\
\text { cattle is allowed to } \\
\text { graze }\end{array}$ \\
\hline $\begin{array}{l}\text { No limits are set but a } \\
\text { treatment of at least } \\
\text { primary sedimentation is } \\
\text { required }\end{array}$ & $\begin{array}{l}\text { Irrigation of } \\
\text { industrial, timber, } \\
\text { fodder, cereal and } \\
\text { oilseed crops, as well } \\
\text { as green areas not } \\
\text { accessible to the } \\
\text { public }\end{array}$ & Localized & \\
\hline
\end{tabular}

(*) Ascaris, Trichuris and Ancylostoma (Westcot and Ayers, 1984).

\section{General considerations about wastewater}

Wastewater discharge has increased in the last decades as a result of the of urban population. Water has become a central element of current environmental and economic policies, as well as a key development factor; all this has given urgency to the need to clean polluted water bodies in order to meet the needs of the population (Peña, 2013). The treatment of wastewater started during the industrial revolution; since then, it has been considered an environmental and social problem. In the nineteenth and twentieth centuries, many studies have tried to understand the composition of wastewater with the aim of devising better ways to remove and dispose wastewater contaminants (Tang, 2004; Parreiras, 2005).

Wastewaters are defined by the NOM-001 (1996) as waters of varied composition from industrial and municipal discharges that can have agricultural and domestic use. In 
addition, these waters contain inorganic elements that may have very different composition, from nutrients such as nitrogen and phosphorus, to toxic and hazardous substances (Domínguez-Mariana, 2004; Sierra, 2011). SEMARNAT (2002) defined wastewaters as waters from municipal, industrial, commercial, service, agricultural, livestock and domestic discharges, or from any other use, including a mixture of them. The classification of wastewaters is based on their origin; they are generally divided into urban and industrial. Urban wastewaters include sewage and domestic washing water, which contain detergents are always somewhat homogeneous in composition.

Industrial wastewaters come from any production, processing or handling process in which water is used; their composition may vary. These waters are more polluted than urban wastewaters, and, therefore, their contaminants are more difficult to remove (Félez-Santafe, 2009).

\section{Purification of municipal wastewater}

The treatment of urban and industrial wastewater is the most effective solution for the purification of effluents. However, it is very important to understand the toxic action of certain substances that can slow the purification process and even nullify the action of the microorganisms involved in the purification of water (Osorio et al., 2010). The treatments aimed at wastewater purification involve a number of physical, chemical and biological steps that seek to recover polluted water and, in many cases, return it to clean water (De la Peña et al., 2013). However, returning treated water to these channels is not recommended because these purification processes do not completely eliminate compounds that may cause damage to ecosystems, such as heavy metals.

The purification process is divided according to the biodegradability of wastewater components (Osorio et al., 2010): 1) the preliminary treatment removes large solid residues such as cans, rags, bottles, etc., as well as fatty contaminants (EPA, 2004); 2) the primary treatment removes suspended solids and organic matter by physical separation using methods such as gravity or chemical sedimentation, or filtration (CRA, $2000)$; 3 ) the secondary treatment removes $90 \%$ of the organic matter, turning it into a sedimentable biological floc (an agglomeration of organic matter, bacteria and minerals). This process is carried out using techniques such as activated sludge, aerated lagoons, trickling filters, biodiscs, and stabilization ponds (Figures 1 and 2) (Rulkens, 2008; Muñoz, 2011). Post-treatments, or tertiary treatments, consist in several anaerobic (for the degradation of organic matter); aerobic or facultative treatments used as a final complement for the removal of organic material and suspended solids. In addition, aerobic processes help remove heavy metals, nutrients and pathogens (CEPIS, 2002; Nelson et al., 2004).

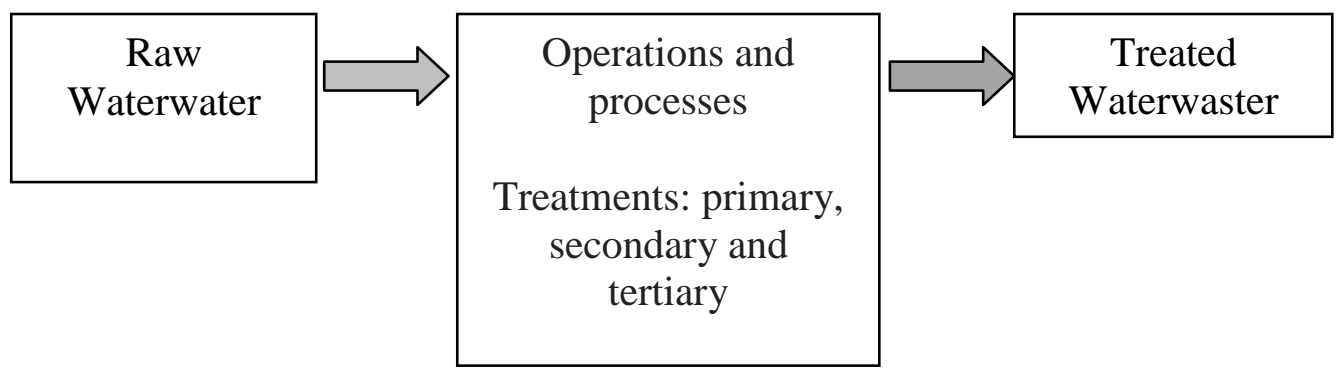

Figure 1. General scheme of wastewater treatment (Crittenden et al., 2005). 


\begin{tabular}{|c|c|c|c|}
\hline \multirow{6}{*}{$\begin{array}{l}\text { Natural } \\
\text { Processes }\end{array}$} & \multirow{2}{*}{$\begin{array}{c}\text { Unit Operations } \\
\text { (Physical processes) } \\
\text { Primary } \\
\text { Treatment }\end{array}$} & $\begin{array}{c}\text { Gravity } \\
\text { precipitation }\end{array}$ & Silting \\
\hline & & $\begin{array}{l}\text { Impermeability of } \\
\text { bodies }\end{array}$ & Filtration grids \\
\hline & \multirow{4}{*}{$\begin{array}{c}\text { Unit Processes } \\
\text { (Chemical Processes } \\
\text { and } \\
\text { biological) } \\
\text { Secondary } \\
\text { Treatment }\end{array}$} & \multirow{2}{*}{$\begin{array}{l}\text { Separation layers } \\
\text { polar and non polar }\end{array}$} & Defatting \\
\hline & & & \multirow{2}{*}{$\begin{array}{c}\text { Flocculation and } \\
\text { coagulation }\end{array}$} \\
\hline & & Abiotic agents & \\
\hline & & $\begin{array}{c}\text { Biotics agents } \\
\text { Tertiary } \\
\text { Treatment }\end{array}$ & $\begin{array}{c}\text { Degradation and } \\
\text { metabolic } \\
\text { absorption }\end{array}$ \\
\hline
\end{tabular}

Figure 2. Operations and unit processes in the treatment of municipal wastewater (Tchobanoglous and Burton, 2005).

In the coagulation process, wastewater contains suspended matter in the form of gels; and by adding metal salts, such substances tend to become unstable and begin a process of aggregation of dissolved organic matter. This promotes the aggregation of organic matter or bacteria, making it easier to remove them from wastewater (Ramírez, 2004).

The tertiary treatment may be aerobic or anaerobic, involving bacteria and protozoa that can be found suspended in the water or, on the contrary, fixed to a surface. In the aerobic processes, microorganisms degrade organic compounds such as sugars, fatty acids and proteins (Tchobanoglous and Burton, 2005). Under constant oxygenation, bacterial communities and suspended solids flocculate first and then precipitate as sludge (activated sludge and lagoons); once they are fixed to a surface, they can be removed by trickling filters and biofilters. In the anaerobic process, organisms act in two stages, a facultative stage and a strict one. In the first stage, known as acidogenic, the organic matter $(\mathrm{OM})$ is broken down to its simplest organic acids; in the second stage, or acetogenic, fatty acids are broken down to its simplest parts and reduced to methane $\left(\mathrm{CH}_{4}\right)$ (Noyola, 1999). However, as in the aerobic process, reactors and anaerobic lagoons can be used in this process, while anaerobic filters can be used in fixed surfaces (Muñoz, 2011).

\section{Wastewater treatment in Mexico}

According to the National Water Commission (CONAGUA, 2007), the wastewater treatment regardless of the treatment of industrial discharges, is an indicator that refers to the percentage of wastewater collected from municipal sewer systems that is treated with activated sludge, and this percentage was $47.5 \%$ for 2012 . However, CONAGUA (2011, 2013a) has recorded that stabilization ponds are the most used treatment for purifying municipal wastewaters in 732 treatment plants in Mexico, followed by activated sludge in 698 plants, while anaerobic upflow reactors are used in 188 plants, and the primary process is only utilized in 21 treatment plants (Figure 3). 


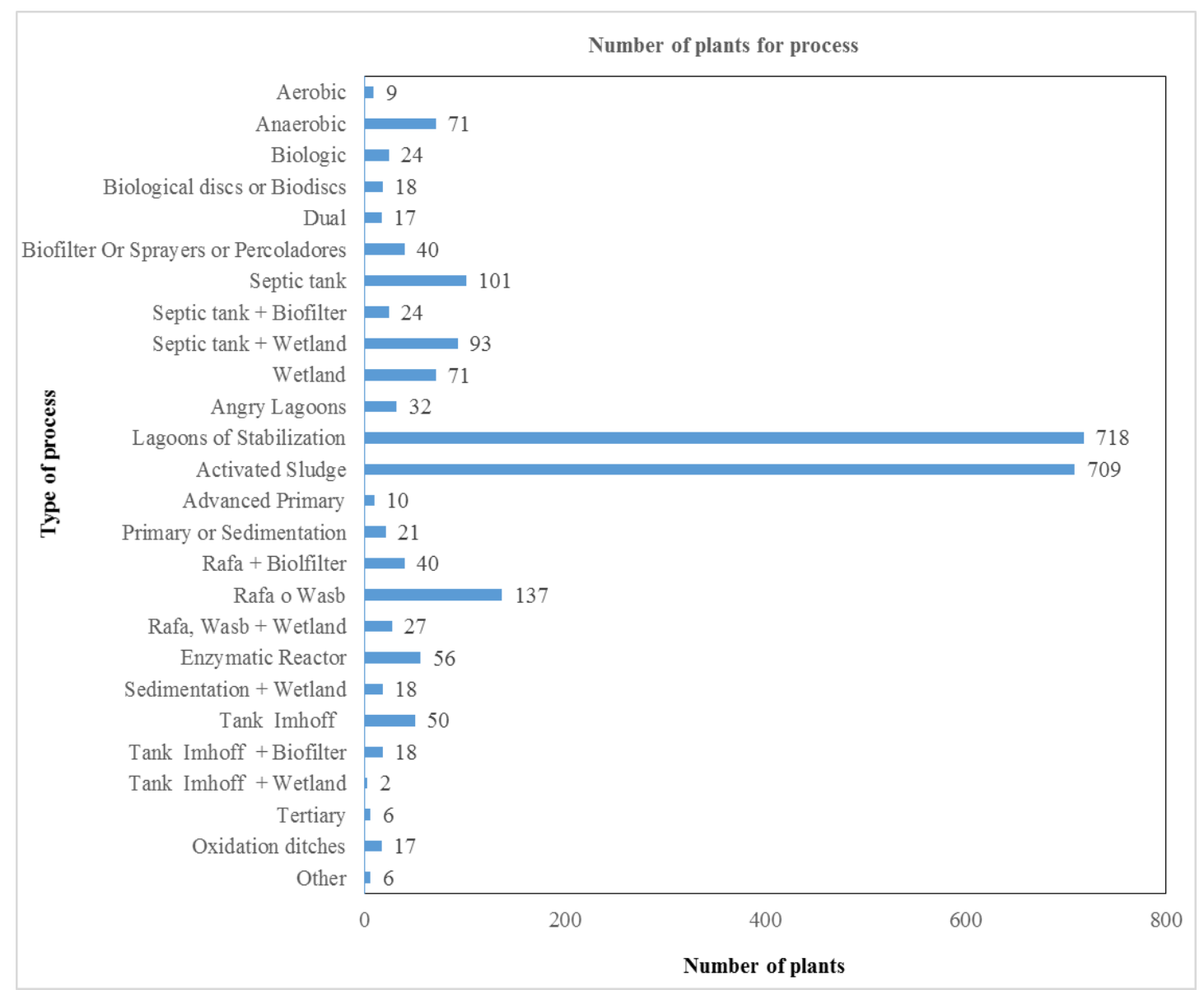

Figure 3. Taken de:Inventario Native of Municipal Plants of Potabilización and of Treatment of Waste water in Operation (CONAGUA, 2014).

\section{Overview of wastewater reuse}

Reusing wastewater is intended to take advantage of this water resource in other activities than those from which it was originated, but by previously subjecting it to a process of purification (Gutiérrez, 2003; Osorio et al., 2010).

In Latin America, about $400 \mathrm{~m}^{3} \mathrm{~s}^{-1}$ of wastewater are discharged into surface water sources; for example, in Colombia, 1,230,193 ha are irrigated with wastewater, of which $27 \%$ is treated wastewater, and $73 \%$ untreated but usually diluted with surface water (Silva et al., 2008). However, there is no complete and reliable information about wastewater reuse in Latin America (Cepis, 2003), and only 8\% of the total wastewater that is generated daily, is treated (WSP, 2007). Thus, irrigation of agricultural areas is done mostly with untreated wastewater; Mexico generates more than half of the wastewater of all Latin America (Post, 2006).

The irrigation infrastructure in Mexico is one of the largest in the world, covering 6.46 million ha, but water availability is increasingly under pressure due to population growth. The distribution of water is based on the demand from the industrial, agricultural and municipal sectors, since there is the need to produce food and provide basic services to increasing human population (Elizondo, 2004). CONAGUA (2009) reported that, in 2007, Mexico generated $243 \mathrm{~m}^{3} \mathrm{~s}^{-1}$ of urban wastewater, of which $32.6 \%$ were treated; however, only $0.53 \mathrm{~km}^{3}$ were treated properly, and at least $6.8 \mathrm{~km}^{3}$ 
of untreated wastewater were discharged into the environment. In 2009, the 2029 water treatment plants operating in the country treated $42 \%$, of watewater, which is equivalent to $88.1 \mathrm{~m}^{3} \mathrm{~s}^{-1}$, of the total of $209.1 \mathrm{~m}^{3} \mathrm{~s}^{-1}$ of the wastewater collected in sewer systems (Mejía et al., 2012). In 2011, 36\% of all municipal wastewater was treated, removing 1.34 million tons of $\mathrm{MO}$, which suggests that the generation of polluting matter will always be above the capacity to remove it; even if there was a notable increase in the number of the water treatment plants, which could reach 2709 by the year 2030, but the volume of wastewater treated would always be well below the total volume generated (SINA, 2012).

The agricultural sector requires the largest volume of water, ranging from $76.7 \%$ to $80 \%$ of the total available water; however, it only uses $46 \%$, meaning that slightly less than half of the water is used for crop production. In contrast, the allocation of public water distribution service is about 14\% (Mejia et al., 2012). Sainz-Santamaria and Becerra (2007) note that not all wastewater is discarded, since the agricultural sector reuses $2.43 \mathrm{~km}^{3}$ each year. However, removing diluted contaminants from untreated and unused wastewater is extremely important. CONAGUA, 2014 brings the conditions that use in the agriculture residual water once (Table 3). In 2006, the World Health Organization issued new guidelines regarding the use of wastewater, excreta and greywater; these guidelines represent a tool for the preventive management of wastewater in agriculture and, thereby, for maximizing public health safety (WHO, 2006). The use of wastewater by farmers reveals an environmental tension between soil pollution and the emission of gases to the atmosphere, as well as jeopardizing human health, due to the toxic substances and pathogens that could enter the food chain. The contribution of $\mathrm{N}$ and $\mathrm{P}$ contained in wastewater consists on reducing the cost of fertilization and increasing the crop production (Monroy, 2013).

Table 3. Plants of treatment of residual water for agricultural reuse for State, in Mexico.

\begin{tabular}{ccc}
\hline State & Number of plants of treatment & $\begin{array}{c}\text { Total of flow treated in the } \\
\text { plants }\left(\mathbf{L ~ ~ ^ { - 1 }}\right)\end{array}$ \\
\hline Aguascalientes & 14 & 424.66 \\
Baja California Sur & 4 & 101 \\
Coahuila & 9 & 2,369 \\
Chihuahua & 2 & 8 \\
Distrito Federal & 5 & 2,319 \\
Durango & 16 & $2,258.2$ \\
Jalisco & 1 & 3 \\
Michoacán & 2 & 105 \\
Morelos & 1 & 100 \\
Nayarit & 2 & 19 \\
Nuevo León & 9 & 265.8 \\
Oaxaca & 1 & 1 \\
Puebla & 23 & 697.4 \\
San Luis Potosí & 4 & $1,295.2$ \\
Sinaloa & 8 & 278.8 \\
Sonora & 7 & 459.9 \\
Tabasco & 1 & 10 \\
Zacatecas & 7 & 130.5 \\
\hline
\end{tabular}

Table realized from the National Inventory of Municipal Plants of Potabilización and of Treatment of Waste water in Operation (CONAGUA, 2014). 
In Mexico, urban wastewater has been used in agriculture for more than 100 years in the Valle del Mezquital, Hidalgo, the largest (100,000 ha) and oldest agricultural region irrigated with wastewater in the world (DFID, 1998). The wastewater generated by Mexico City and surrounding areas is the main source for the agricultural development of the Mezquital valley, in where there is paradoxically low availability of drinking water (Flores et al., 1997). The organic matter contained in the wastewater improves soil conditions and plant productivity, but also contributes to soil pollution, and endangers plants, environment, and human health (León-Suematsu, 1995).

Furthermore, the use of wastewater should be restricted due to its high content of salts, heavy metals, bacteria and viruses (Table 4) (Zekri and Koo, 1994), by which several developed and developing countries have regulated its utilization. From the environmental point of view, the reuse of wastewater in desert areas, in where water resources are scarce, also offers several advantages (Crook, 1984). This raises the need to develop appropriate management and monitoring techniques for allowing better control of this resource (Bouwer, 1992).

Table 4. General composition of wastewater (DSEUA, 2000).

\begin{tabular}{ccc}
\hline Parameter & Units & Symbol \\
\hline Chemical demand of oxygen & $\mathrm{mg} \mathrm{L}^{-1}$ & $\mathrm{DQO}$ \\
Biochemical demand of oxygen & $\mathrm{mg} \mathrm{L}^{-1}$ & $\mathrm{DBO}$ \\
& & $\mathrm{SST}$ \\
Total suspended solids & $\mathrm{mg} \mathrm{L}^{-1}$ & $\mathrm{SSV}$ \\
Suspended solids & $\mathrm{mg} \mathrm{L}^{-1}$ & $\mathrm{~N}^{-\mathrm{NH}_{3}}$ \\
Ammonia nitrogen & $\mathrm{mg} \mathrm{L}^{-1}$ & $\mathrm{PO}_{4}^{-2}$ \\
Organic phosphorus & $\mathrm{mg} \mathrm{L}^{-1}$ & \\
Total coliforms & $\mathrm{NMP} / 10 \mathrm{~mL}$ & \\
Fecal coliforms & $\mathrm{NMP} / 100 \mathrm{~mL}$ & \\
Helminth eggs & $\mathrm{HH} \mathrm{L}$ &
\end{tabular}

MPN=Most Probable Number.

\section{Some case studies carried out in Mexico on the use of wastewater in the agriculture}

Wastewater used for irrigation includes all possible degrees of epuration, from untreated water to those from tertiary treatment. In Mexico, some studies have been conducted to determine the quality of wastewater used for irrigation and the effect that this irrigation produces on the environment. Among them are the works performed at the Mezquital Valley by Siebe and Cifuentes (1993) who evaluated the epidemiological impact of wastewater used in agriculture at irrigation districts 03 and 100 . The aim was to compare rain fed agricultural areas, at the State of Hidalgo. It was found prevalence of Ascaris lumbricoides, Giardia lambia and Entamoeba histolytica among the population. They also reported that the wastewater contains high concentrations of indicator organisms: 108 fecal coliforms $/ 100 \mathrm{~mL}$ and 70 eggs of L- $^{1}$. It was concluded that fecal coliform concentration varies over time. Chilton et al. (1996) reported that the infiltration of wastewater has changed the hydro geochemical along the Valle del Mezquital. Castañón et al. (1995) reported that in the Valle de León, which is irrigated with wastewater with high chromium contents, it generates negative environmental impacts by contamination of groundwater, soil and the increase of infectious diseases among the population because the wastewater is used without any purification treatment. On the other hand, the same area has been irrigated with wastewater for over 
30 years on crop rotation of sorghum, wheat and alfalfa (Esteller, 2002). On the positive side it should be noted the increase of agricultural production in these areas and the improving of soil characteristics.

Sarabia-Meléndez et al. (2011) found that due to the limited availability of groundwater for irrigation use, some farmers in the municipalities of San Luis Potosi and Soledad de Graciano Sánchez, SLP, Mexico have long been used for irrigation of peri-urban agricultural areas, wells located in deep and shallow aquifers in the valley, and wastewater from domestic and industrial discharges. This causes a complex picture of crop production and public health risk by the presence of fecal coliforms.

Lucho-Constantine et al. (2005a) assessed the accumulation and distribution of the major elements in agricultural soils from 03 (DR03) District in the state of Hidalgo, Mexico, irrigated with untreated wastewater for an average of 20 years. They concluded that there is a significant correlation between the run time, the contents of $\mathrm{Pb}, \mathrm{Cd}, \mathrm{Cr}, \mathrm{B}$, M. O., organic C and easily exchangeable fraction. Meanwhile, Flores-Magdaleno et al. (2011) also conducted a study in Hidalgo on the effect of heavy metals in wastewater in soils of the municipality of Mixquihula. They found that when considering the limits established in Spain, concentration of As, $\mathrm{Ni}$ and Cd exceeds permissible level in 20,60 and $60 \%$ respectively of the analyzed samples of wastewater and concentration of extractable metals in agricultural soils is present as follows: $\mathrm{Pb}>\mathrm{Ni}>\mathrm{Cd}>\mathrm{Como}>\mathrm{Cr}>$ $\mathrm{Hg}$. The irrigation water presents no problems for use depending on the concentration of $\mathrm{Hg}, \mathrm{Cr}$ and $\mathrm{Zn}$. However, $\mathrm{Pb}$ concentration exceeds the maximum allowable.

\section{Use of bioremediation techniques for wastewater treatment}

The term "treatment technology" refers to any unit operation or series of unit operations that alter the composition of a hazardous or pollutant substance through chemical, physical or biological actions, so as to reduce the toxicity, mobility or volume of the contaminated material (EPA, 2004).

Bioremediation is used for the restoration of ecological damage through the optimization of certain living organisms (plants, fungi and bacteria, for instance) which are able to remove, degrade or transform toxic organic compounds into harmless or less toxic metabolic products (Van Hamme et al., 2003; Garbisu et al., 2002). The most common bioremediation techniques are phytoremediation, electrobiorremediation, leaching, chelation, methylation and precipitation (Martínez-Prado et al., 2011).

Phytoremediation consists on the use of plants and associated rhizosphere microorganisms that may favor the recovering contaminated water, soil and sludge. This biotechnology can be used in situ by which has no expensive costs nor secondary consequences, and consequently is an environmentally and ecologically friendly technology (Barceló and Poschenrieder, 2003; Nuñez et al., 2004; 2006; DelgadilloLópez et al., 2011). Phytoremediation comprises mechanisms that reduce, in situ or ex situ, the concentration of several toxic compounds through physiological and biochemical processes performed by plants and microorganisms that remove (phytoextraction, phytodegradation or phytovolatilization), or immobilize (phytostabilization and rhizofiltration) contaminants from soil or water (Bernal et al., 2007). It should be noted that not all of these mechanisms are used in phytoremediation of wastewater (Table 5) (Delgadillo-Lopez et al., 2011). 
Table 5. Bioremediation techniques commonly used for wastewater.

\begin{tabular}{lll}
\hline Process & Mechanism & Contaminants \\
\hline Phytoextraction & Hyperaccumulation & Inorganic \\
Phytodegradation & $\begin{array}{l}\text { Using plants and associated } \\
\text { microorganisms to degrade } \\
\text { contaminants }\end{array}$ & Organic \\
Rhizofiltration & $\begin{array}{l}\text { Using roots to absorb and adsorb } \\
\text { contaminants from water }\end{array}$ & Organic and inorganic \\
\hline
\end{tabular}

Taken from Ghosh and Singh (2005).

The plants recommended for phytoremediation should be fast-growing, have high biomass production and tolerance, and accumulate metals; and they should preferably be local species, representative of the ecosystem and, finally, easily harvestable (Nuñez et al., 2009; Delgadillo-Lopez et al., 2011). Phytoremediation of heavy metals has been successful due to the ability of plants to absorb and accumulate these inorganic contaminants (Adriano, 2004; Lopez-Delgadillo et al., 2011), but plants differ on their capability for absorbing and accumulate toxic metals from water, soil and sludge (Delgadillo-López et al., 2011). Thus, plants have specific strategies against the presence of metals in their environment; some base their resistance on possessing efficient mechanisms for metal exclusion that restrict their transport to aerial parts; but others accumulate metals in the aerial parts as nontoxic chemical species (Llugany et al., 2007). The most common plants used for decontaminating heavy metals are Impatiens balsamina (L.), Calendula officinalis (L.), Alcea rosea L., Spirodela polyrrhiza (L.) Schleid., Brassica juncea (L.) Czern., Phragmites australis (Cav.) Trin. ex Steud., Zea mays (L.)., Medicago sativa (L.)., and Lupinus luteus (L.).

Some of these species are characterized as hyperaccumulator plants due to their capability to accumulate high amount of heavy metals in their tissues (Arenas et al., 2011).

Rhizofiltration is a technique similar to phytoextraction that can be used to decontaminate wastewater by filtering it through a mass of roots of hydroponically grown plants, so that the dissolved contaminants are adsorb or absorbed and accumulated (Nuñez et al., 2009; Cherian and Oliveira, 2005). Rhizofiltration processes have been directed to the wastewater treatment in Mexico, and some studies have used hydroponic Helianthus annuus (L.). and Mentha deriva (L.)., but the process has not been $100 \%$ effective, as these plants achieved only a partial removal of nitrates $(60 \%)$ and phosphates, 40\% (Torres-Calderón, 2009). Other studies have shown that, under hydroponic conditions, Vetiveria zizanioides (L.) (Seguier.), reduced the total nitrogen levels from $100 \mathrm{mg} \mathrm{L}^{-1}$ to $6 \mathrm{mg} \mathrm{L}^{-1}$ (94\% efficiency), while the total phosphorus level was diminished from $10 \mathrm{mg} \mathrm{L}^{-1}$ to $1 \mathrm{mg} \mathrm{L}^{-1}$ (90\% efficiency) (Truong et al., 2000).

The use of macrophytes to remove heavy metals from wastewater has produced good results. Nuñez et al. (2004) indicate that Salvinia minima (Seguier.), a tropical water fern, is very efficient for removing $\mathrm{Pb}$ and $\mathrm{Cd}$. Furthermore, Alvarez et al. (2004) indicate that the water lily, despite being a problematic weed, has the ability to absorb heavy metals through its root system; and its efficiency of removing $\mathrm{Cr}$ from tanneries 
is about $75 \%$, exceeding the provisions of Norm 002 for the content of chromium in wastewater. Bustamante and González (2013) report that Myriophyllum aquaticum (L.) can remove $53.5 \%$ of $\mathrm{Cr}(\mathrm{VI})$ and $30 \%$ of $\mathrm{Cu}$ on average. Shahabaldin et al. (2015) described several sucessful studies of phytoremediation using Eichhornia crassipes (Mart) (water hyacinth) for removing heavy metals.

Among the studies conducted with E. crassipes (Mart) in wetlands, Lissy et al. (2011) reported up to $65 \%$ removal of $\mathrm{Cr}$ and $\mathrm{Cu}$, while there are reports that the removal of $\mathrm{Zn}, \mathrm{Cu}, \mathrm{Cd}$ and $\mathrm{Cr}$ decreases in industrial wastewater (Yapoga et al., 2013).

The roots of E. crassipes (Mart) have the ability to quickly adsorb metals from an artificial wastewater system with different concentrations of $\mathrm{NiCl}_{2}(1,2,3$ and $4 \mathrm{mg} \mathrm{L}$ ${ }^{1}$ ), indicating that $\mathrm{Ni}$ was adsorbed through the roots in greater proportion rather than allocated in the aerial part (Gonzalez et al., 2015). The accumulation of metals by $E$. crassipes (Mart) is affected due to the age of the plant, temperature, $\mathrm{pH}$, light intensity, the concentration of toxic metals, and competition with other ions and, furthermore, the absorption of $\mathrm{Cr}$ (IV) is favored by the presence of phenol, which is used as carbon and energy source (Gupta and Balomajumder (2015). Ajayi and Ogunbayo (2012) described that E. crassipes (Mart) is more efficient for removing $\mathrm{Cd}(94 \%$ removal) than $\mathrm{Cu}$ and Fe from wastewater from textile, metallurgical or pharmaceutical industries.

The use of aquatic plants to remove radioactive metals such as uranium has shown good results. Callitriche stagnalis (Scop).,Potamogeton natans (L.)., and Potamogeton pectinatus (L.)., native plants from central Portugal with high biomass accumulation are efficient species for being utilized for phytofiltration of uranium from water contaminated $\left(500 \mathrm{~g} \mathrm{U} \mathrm{L}^{-1}\right)$, obtaining significant decreases in the content of $U$, and good accumulation of in plant tissues (Pratas et al., 2014). Ferrera-Cerrato et al. (2006) indicate that plants used in phytoremediation are characterized for their tolerance to extreme concentrations of organic or inorganic compounds, and for their physiological mechanisms involved in such resistance, tolerance, and survivability in contaminated water.

Some tree species can also be used in phytoremediation of wastewater. Guidi et al. (2014) demonstrated the high potential of willow plants (Salix alba L.) for phytoremediation of large volumes of wastewater in short rotations. For instance, willows plants were used to treat $5200 \mathrm{~m}^{3} \mathrm{ha}^{-1}$ of water with a high content of $\mathrm{N}_{-} \mathrm{NH}_{4}^{+}$, achieving high decontamination efficiency mainly due to the high evapotranspiration rate and nutrient retention.

Microalgae is another biological alternative to remove $\mathrm{N}$ and $\mathrm{P}$ from wastewater (Unnithan, 2014). Chlorella and Scedesmus are common microalgae used for removing heavy metals (Garza et al., 2010; Canizares et al., 2013). Travieso et al. (2004) reported that the use of Chlorella vulgaris for tertiary treatment of swine wastewater in which the content of N and $\mathrm{P}$ was reduced, while Scenedesmus dimorphus was able to remove $\mathrm{NH}_{4}{ }^{+}$and $\mathrm{P}$ in secondary treatments under bioreactor processes (Gonzalez et al., 1997). Other experiments under laboratory conditions reported that the removal of $\mathrm{Cd}$ was higher with $C$. vulgaris when compared with Scedemus acutus, but both species achieved a removal efficiency of Cr (VI) up to $80 \%$ (Canizares et al., 2013). The use of Chlorella sp. for bioremediation of aquaculture wastewater has also shown good results. Modh et al. (2015) reported a correlation between the growth kinetics of Chlorella sp. and the nutrients $\mathrm{N}-\mathrm{NH}_{4}{ }^{+}$and $\mathrm{P}-\mathrm{PO}_{4}$ contained in aquaculture wastewater; indicating that the optimal inoculation of Chlorella was $30 \%(\mathrm{v} / \mathrm{v})$, by which the removal of $\mathrm{N}$ $\mathrm{NH}_{4}{ }^{+}$and $\mathrm{P}_{-} \mathrm{PO}_{4}$ was 98.5 and 92.2 4\%, respectively. In addition, the Azolla-Anabaena 
symbiosis produced some benefits in the bioremediation of wastewater. Some studies reported that this symbiosystem accumulate $13.3 \mathrm{~g} \mathrm{~kg}^{-1}$ of $\mathrm{Cd}, 2.27 \mathrm{~g} \mathrm{~kg}^{-1}$ of Se, and $3.36 \mathrm{~g} \mathrm{~kg}^{-1}$ of $\mathrm{Cu}$ (Sánchez-Viveros et al., 2013). The Table 6 lists several of bioremediation studies conducted with wastewater in Mexico, and it is important to note that, until 2014, the research on bioremediation in Mexico mainly focused in soils contaminated with hydrocarbons or heavy metals.

Table 6. Research lines carried out in various institutions and phytoremediation projects for wastewater in Mexico.

\begin{tabular}{|c|c|c|c|c|}
\hline $\begin{array}{c}\text { Research line } \\
\text { and projects being developed }\end{array}$ & Contaminant & Institution & State & Year \\
\hline $\begin{array}{l}\text { Phytoremediation of wastewater from pig farms } \\
\text { and coffee processing plants. }\end{array}$ & $\begin{array}{l}\text { Organic } \\
\text { matter } \\
\text { and nutrients }\end{array}$ & INECOL & Veracruz & 1994 \\
\hline $\begin{array}{l}\text { Biosorption of } \mathrm{Pb} \mathrm{Cd} \text {, cadmium and As using two } \\
\text { tropical floating aquatic plants (Spirodela } \\
\text { polyrrhiza and Salvinia minima) in plug flow } \\
\text { lagoons }\end{array}$ & Heavy metals & INECOL & Veracruz & 2001 \\
\hline $\begin{array}{l}\text { Development of a bioadsorbent from the biomass } \\
\text { of Spirulina sp. }\end{array}$ & Heavy metals & INECOL & Veracruz & 2001 \\
\hline $\begin{array}{l}\text { Removal of Ar from mining effluents and } \\
\text { groundwater with native accumulating plants } \\
\text { through the implementation, at pilot-scale, of } \\
\text { constructed wetlands }\end{array}$ & Heavy metals & CIMAV & Chihuahua & 2001 \\
\hline $\begin{array}{l}\text { Electrochemical removal of metals from plant } \\
\text { biomass or biosorbents. }\end{array}$ & Heavy metals & CIDETEQ & Querétaro & 2001 \\
\hline $\begin{array}{l}\text { Use of water hyacinth (Eichhornia crassipes) for } \\
\text { the removal of heavy metals from contaminated } \\
\text { water. }\end{array}$ & Heavy metals & CIDETEQ & Querétaro & 2001 \\
\hline $\begin{array}{l}\text { Production of phytochelatins by Salvinia minima } \\
\text { exposed to } \mathrm{Pb} \text { and } \mathrm{As} \text {. }\end{array}$ & Heavy metals & CICY & Yucatán & 2001 \\
\hline $\begin{array}{l}\text { Enhancement of the removal capacity of } \mathrm{Pb} \text { and } \\
\text { As by aquatic plants }\end{array}$ & Heavy metals & CICY & Yucatán & 2001 \\
\hline $\begin{array}{l}\text { Removal of contaminants and pathogens from } \\
\text { wastewater by the vertical root method, using } \\
\text { plants from the region }\end{array}$ & $\begin{array}{l}\text { Organic } \\
\text { matter } \\
\text { and } \\
\text { pathogens }\end{array}$ & UADY & Yucatán & $\begin{array}{c}98- \\
02\end{array}$ \\
\hline $\begin{array}{l}\text { Phytoremediation of heavy metals in the Tenorio } \\
\text { tank and its environmental impact }\end{array}$ & Heavy metals & UASLP & $\begin{array}{l}\text { San Luis } \\
\text { Potosi }\end{array}$ & 2002 \\
\hline $\begin{array}{l}\text { Phytoremediation and bioadsorption for the } \\
\text { sustainable use of water }\end{array}$ & Heavy metals & INECOL & Veracruz & 2004 \\
\hline $\begin{array}{l}\text { Phycoremediation (using algae) and } \\
\text { phytoremediation (using plants) for removing } \\
\text { contaminants from wastewater }\end{array}$ & & INECOL & Veracruz & 2006 \\
\hline
\end{tabular}

Modified from Nuñez et al., 2004. 


\section{Perspectives and conclusions}

In general, the Mexican agricultural sector is the main consumer of water resources, whose availability is scarce in some areas, making it necessary to direct bioremediation techniques to reuse wastewater from municipal sources. However, it is advisable to treat wastewater before using it, but in practice, it is used without prior treatment. Thus, bioremediation should be considered as an efficient technology for cleaning and reusing wastewater.

Bioremediation is a low-cost technology that does not require complex infrastructure, and can be used to treat large volumes of wastewater. In developed countries, bioremediation is highly efficient for removing, transforming or degrading different types of contaminants found in wastewater, particularly using the mechanisms of phytoextraction and rhizofiltration.

Wastewater is mostly used to irrigate horticultural crops for direct consumption, due to its contribution on plant nutrition, which reduces crop costs due to limited fertilizer application. However, this practice has potential risks to public health, and thus, it should be reconsidered, and the prior treatment of wastewater must be encouraged.

Plants are able to adsorb, absorb, metabolize, accumulate, stabilize, or even volatilize organic or inorganic contaminants. As a biotechnology, phytoremediation offers advantages over conventional methods of wastewater remediation. However, further research is needed to reassess and validate the benefits and the effectiveness of bioremediation/phytoremediation systems for cleaning and detoxifying wastewaters, particularly in countries like Mexico.

\section{REFERENCES}

[1] Adriano, D. C., Wenzel, W. W., Vangronsveld, J., Bolan, N. S. (2004): Role of assisted natural remediation in environmental cleanup. - Geoderma 122:121-142.

[2] Ajayi, T.O., Ogunbayo, A.O. (2012): Achieving environmental sustainability inwastewater treatment by phytoremediation with wáter hyacinth (Eichhornia crassipes). - Journal Sustainable Development 5(7): 80-90.

[3] Arenas, D. A., Lué-Merú, M., Torres G. (2011): Evaluación de la planta Lemna minor como biorremediadora de aguas contaminadas con mercurio. - Avances en Ciencias e Ingeniería 2(3): 1-11.

[4] Atlas digital del agua en México. (2012): - CONAGUA 133.

[5] Barceló, J., Poschenrieder, C. (2003): Phytoremediation: principles and perspectives. Institut d' Estudis Catalans, Barcelona. - Contributions to Science 2(3): 333-344.

[6] Bernal, M., Clemente, R., Vázquez, S., Walker D. (2007): Aplicación de la fitorremediación a los suelos contaminados por metales pesados en Aznalcó 1lar. Ecosistemas 16(2): 1-14.

[7] Bouwer H. (1992): Agricultural and municipal use of wastewater. - Water Science and Technology 26: 7-8.

[8] Bustamante, G. J. D., González, R. M. (2013): Eficiencia de las plantas acuáticas Pistia stratiotes L. y Myriophyllum aquaticum L. en la remoción de metales pesados $\mathrm{Ni}, \mathrm{Cr}(\mathrm{VI})$ y $\mathrm{Cu}$ en agua de los canales de Xochimilco. - Revista. E-Bios. Número especial: 56-61.

[9] Cañizares-Villanueva, R. (2000): Biosorción de metales pesados mediante el uso de biomasa microbiana, Departamento de Biotecnología y Bioingeniería. - Revista Latinoamericana de Microbiología 42: 131-143.

[10] Cañizares-Villanueva, R., Montes-Horcasitas, Ma. del C., Perales-Vela, H. G. (2013): 
Las microalgas en la biorremediación acuática: Una alternativa biotecnológica. - In: Alarcón, Ferrera-Cerrato (Eds.) Biorremediación de suelos y aguas. Trillas, México, D.F. pp. 217-234.

[11] Castañón, V.M., Morales, A., Pérez-Hernández, H. (1995): Efectos del reuso de aguas residuales sobre los recursos de agua subterránea para uso urbano en el Valle de León, Guanajuato. -Reporte técnico GSA/95/2. Comisión Nacional del Agua, British Geological Survey y Sistema de Agua Potable y Alcantarillado de León.

[12] CEPIS. (2002): Resumen ejecutivo de proyecto regional sistemas integrados de tratamiento y uso de aguas residuales en América Latina: realidad y potencial. Centro Panamericano de Ingeniería Sanitaria y Ciencias del Ambiente, Lima, Perú, 110.

[13] Chaney, R. L., Li, Y. M., Brown, S. L., Homer, F.A., Malik, M., Angle, J. S., Baker, A. J. M., Reeves, R. D., Chin, M. (2000): Improving metal hyperaccumulator wild plants to develop commercial phytoextration systems approaches and progress. - In: Terry , N., Buñuelos, G. (Eds.) Phytoremediation of Contaminated Soil and Water. Lewis Publishers, Boca Raton, Florida.

[14] Cherian, S., Oliveira, M. (2005): Transgenic plants in phytoremediation: recent advances and new possibilities. - Environmental Science \& Technology 39: 93779390.

[15] Chilton, P. J., Morris, B. L., Foster, S. (1996): Los recursos hídricos subterráneos y la disposición de aguas residuales urbanas, interacciones positivas y negativas. -VII Curso Internacional OMS-PNUMA-GEMS/OPS-CEPIS/ODA-BGS. 42 pp.

[16] CONAGUA. (2007): Gestión del agua en cuencas y acuíferos sobreexplotados 2000.Comisión Nacional del Agua, Ediciones CONAGUA, México, 57.

[17] CONAGUA. (2009): Situación del subsector agua potable, alcantarillado y saneamiento. - Comisión Nacional del Agua. Edición 2009, SEMARNAT, México, 167.

[18] CONAGUA. (2011): Estadísticas del agua en México. - Comisión Nacional del Agua, SEMARNAT, México, $106 \mathrm{pp}$.

[19] CONAGUA. (2013a): Situación del subsector agua potable, alcantarillado y saneamiento. - Comisión Nacional del Agua, SEMARNAT, México, 337.

[20] CONAGUA. (2014): Inventario nacional de plantas de tratamiento de agua residual, diciembre 2013. - SEMARNAT, México. 304 pp.

[21] CONAGUA. (2014): Inventario nacional de plantas de tratamiento de agua residual, diciembre 2014. - SEMARNAT, México. 308 pp

[22] Corinne, P. R., Zhao, F. L., McGrath, P. (2006): Phytotoxicity of nickel in a range of European soils: Influence of soil properties, Ni Solubility and speciation. Environmental Pollution 145: 596-605.

[23] CRA. (2000): Reglamento técnico del sector de agua potable y saneamiento básico RAS - 2000, Sección II, Título E, Tratamiento de aguas residuales. - Comisión de Regulación de Agua Potable y Saneamiento Básico, Bogotá, D.C. Colombia, 145.

[24] Crittenden, J. C., Trussel, R., Hand D., Howe K., Tchobanoglous G. (2005): Water treatment: Principles and design, 2th edition. - John Wiley and Sons, New Jersey, USA, 1948.

[25] Crook, J. (1984): Health and regulatory considerations. - In: Pettygrove, G., Asano, T. (Eds.) Irrigation with reclaimed municipal wastewater, California state water resources control board. Sacramento, California. Published by Lewis Publishers, Chesea, Michigan, U.S.A, 101-149.

[26] De la Peña, M. (2013): Tratamiento de aguas residuales en México. - Banco Interamericano de Desarrollo, Sector de Infra-estructura y Medio Ambiente: 42.

[27] Delgadillo-López, A. E., González-Ramírez, C. A., Prieto-García, F., VillagómezIbarra, J. R., Acevedo-Sandoval, O. (2011): Fitorremediación: una alternativa para eliminar la contaminación. - Tropical and subtropical agroecosystems 14(2): 597-612. 
[28] DSEUA. (2000): Manual de tratamiento de aguas negras. - Departamento de Salud de los Estados Unidos de América, Limusa, Noriega Editores, México.

[29] DFID. (1998): Impact of wastewater reuse on groundwater in the Mezquital Valley, Hidalgo State. - Department for International Development, Mexico, CAN, BGS, LSHTM and UB.

[30] Domínguez-Mariana, E., Carrillo-Chávez, A., Ortega, A. (2004): Wastewater reuse in valsequillo agricultural area, Mexico: environmental impact on groundwater. - Journal of Water Air and Soil Pollution 155: 251-267.

[31] Elizondo, A. J. L., Esquivel, G. G., Delgado, W. M., Cruz, Q. R., Sánchez, G. G. (2004): Prospectiva de la demanda de agua en México 2000-2030, Fundación Gonzalo Río Arronte, Fundación Javier Barros Sierra, 105.

[32] EPA. (2004): Primer for Municipal Wastewater Treatment Systems. - Environmental Protection Agency, Washington DC, United States, 30.

[33] Esteller, M.V. (2002): Vulnerabilidad de acuíferos frente al uso de aguas residuales y lodos en agricultura. -Revista Latino Americana de Hidrogeologia 2:103-113.

[34] Félez-Santafé, M. (2009): Situación actual del estado de la depuración biológica. Explicación de los métodos y sus fundamentos.

[35] Ferrera-Cerrato, R., Rojas-Avelizapa, N. G., Poggi-Varaldo, H. M., Alarcón A., Cañizares-Villanueva, R. O. (2006): Procesos de biorremediación de suelo y agua contaminados por hidrocarburos del petróleo y otros compuestos orgánicos. - Revista Latinoamericana de Microbiología 48(2): 179-187.

[36] Flores, L., Hernández, G., Alcalá, R., Maples, M. (1997): Total contents of cadmium, copper, manganese and zinc in agricultural soils irrigated with wastewater from Hidalgo, Mexico City. - Revista Internacional de Contaminación Ambiental 8: 37-46.

[37] Flores-Magdaleno, H., Mancilla-Villa, O. R., Mejía-Saenz, E., Olmedo-Bolaños, Ma. del, C. Bautista-Olivas, A. L. (2011): Heavy metals In agricultural soils and Irrigation wastewater of Mixquiahuala, Hidalgo, Mexico. - African Journal of Agricultural Research 6(24): 5505-5511.

[38] Garza, M. T., Almaguer, V., Rivera, J., and Loredo, J. (2010): Bioingeniería aplicada a una columna empacada con Chorella sp. Inmovilizada para la remoción de metales pesados. - Ciencia UNAL 13(2): 174-177.

[39] Garbisu, C., Amézaga, I., Alkorta, I. (2002): Bioremediación y ecología. Ecosistemas 11(3): 5-12.

[40] Ghosh, M., Singh, S. P., (2005): A review on phytoremediation of heavy metals and utilization of its by-products. - Applied Ecology and Environmental Research 3:1-18.

[41] González, I. E., Caziñares, R. O., Baena, S. (1997): Efficiency of ammonia and phosphorus removal from a Colombian agroindustrial wastewater by microalgae Chorella vulgaris and Scenedesmus dimorphus. - Bioresource Technology 60:259262.

[42] González, C. I., Maine, M. A., Cazenave, J., Hadad, H. R., Benavides, M. P. (2015): $\mathrm{Ni}$ accumulation and its effects on physiological and biochemical parameters of Eichhornia crassipes. - Environmental Experimental Botany 117: 20-27.

[43] Guidi, W. N., Voicu, A., Labrecque, M. (2014): Willow short-rotation coppice for treatment of polluted groundwater. - Ecological Engineering 62:102-114.

[44] Gupta, A., Balomajumder, C. (2015): Removal of Cr (VI) and phenol using water hyacinth from single and binary solution in the artificial photosynthesis chamber. Journal of Water Process Engineering 7: 74-82.

[45] Gutiérrez, J. (2003): Reuso de agua y nutrientes, Cub@: Medio Ambiente y Desarrollo. - Revista electrónica de la Agencia de Medio Ambiente 3(4):1-11.

[46] Hernández-Acosta, E., Quiñones-Aguilar, E. E., Cristóbal-Acevedo, D., RubiñosPanta, J. E. (2014): Calidad biológica de aguas residuales utilizadas para riego de cultivos forrajeros en Tulancingo, Hidalgo, México. - Revista Chapingo, Serie Ciencias Forestales y del Ambiente 20(1): 89-99. 
[47] Hernández, S. G., Flores, V. M., Maples, M. G., Solorio, M. R., and Hernández, S. D. (1993): - Actas del XII Congreso Latinoamericano de la Ciencia del Suelo. Salamanca España 1666 p.

[48] INEGI. (2102): Anuario estadístico de los Estados Unidos Mexicanos. - Instituto Nacional de Geografía y Estadística, México. XV 797 p.

[49] Lissy, P. N. M., Madhu, G. (2011): Removal of heavy metals from wastewater using water hyacinth, ACEEE Int. - Journal Transportation Urban Development 1: 48-52.

[50] León-Suematsu, G. (1995): Aspectos Sanitarios del Uso de aguas residuales. Presentado en el Curso Regional el Tratamiento y Reutilización de Aguas, MéridaVenezuela, 13 de marzo al 7 de abril del 1995, Lima: CEPIS.

[51] Llugany, M., Tolrà, R., Poschnrieder, C., Barceló, J. (2007): Hiperacumulación de metales: ¿una ventaja para la planta y para el hombre?. - Ecosistema 16 (2): 4-9.

[52] Lucho-Constantino, C.A., Álvarez, M., Beltrán, R.I., Prieto, F. Poggi, H. (2005a): A multivariate analysis of the accumulation and fractionation of major and trace elements in agricultural soils in Hidalgo State, Mexico irrigated with raw wastewater. Environmental International 31(3):313-23

[53] Martínez-Prado, A., Pérez-López, M., Pinto-Espinoza, J., Gurrola-Nevarez, B., OsorioRodríguez, A. (2011): Biorremediación de suelo contaminado con hidrocarburos empleando lodos residuales como fuente alterna de nutrientes. - Revista Internacional de Contaminación Ambiental 27(3): 241-252.

[54] Méndez-García, L., Rodríguez-Domínguez, L., Palacios-Mayorga, S. (2000): Impacto del riego con aguas contaminadas, evaluado a través de la presencia de metales en suelos. - Terra 18: 279-288.

[55] Mejía, M. E., Siebe, C., Paillés, C.A. (2012): Proyecto de desarrollo de capacidades para el uso seguro de aguas servidas en agricultura. - (FAO, WHO, UNEP, UNUINWEH, UNW-DPC, IWMI e ICID), México.

[56] Mohd, N. N., Abu, B. N. S., Lananan, F., Abdul, H. S. H., Lam S. S., Jusoh, A. (2015): Treatment of African catfish, Clarias gariepinus wastewater utilizing phytoremediation of microalgae, Chlorella sp. with Aspergillus niger bioharvesting. Bioresource Technology 190:492-498.

[57] Monroy, H. O. (2013): Manejo sustentable del agua en México. - Revista. UNAM. mx 14(10): 1-15.

[58] Muñoz, C. A. (2011): Tratamiento biológico de las aguas residuales de la cuenca central de México. Evaluación de los métodos empleados. - Tesis de Maestría en Ciencias, Instituto Politécnico Nacional, D.F., México.

[59] Noyola, R. A. (1999): Una experiencia en el Desarrollo de tecnología biológica para el tratamiento de aguas residuales. - Interciencia 24 (3): 169-172.

[60] Núñez, R.A., Meas, V. Y., Ortega, B. R., Olguín, J. E. (2004): Fitorremediación: fundamentos y aplicaciones. - Ciencia@UAQ 2(1):69-82.

[61] Nuñez R., Meas, Y., Ortega, R., Olguín, E. (2009): Rizofiltración, lixiviación y electro-recuperación: una propuesta integral para el tratamiento de aguas contaminadas con plomo a partir del lirio acuático (Eichhormia crassipes). - Ciencia@UAQ 2(1):1731.

[62] Olmos, M. A., Alarcón Herrera, M. T. (2014): Impacto ambiental generado por el uso de osmosis inversa en la remoción de arsénico para la obtención de agua potable. Revista Ambiental 5(1): 1-5.

[63] Osorio, R. F., Torres, R. J. C., Sánchez, B. M. (2010): Tratamiento de aguas para la eliminación de microorganismos y agentes contaminantes. - Ed Díaz de Santos, Albanzas 2. Madrid, España.

[64] Parreiras, S. (2005): Curso sobre tratamento de esgoto por disposicao no solo. Fundaçao Estudual do Meio Ambiente (FEAM), Belo Horizonte, Brasil, 40.

[65] Pratas, J., Paulo, C., Favas, J. C. P., Venkatachalamd, P. (2014): Potential of aquatic plants for phytofiltration of uranium-contaminated waters in laboratory conditions. - 
Ecological Engineering 69:170-176.

[66] Peña, M., Ducci, J., Zamora, V. (2013): Tratamiento de aguas residuales en México. Banco Interamericano de Desarrollo, División de Agua y Saneamiento. IDB-TN-524.

[67] Pescod, M. (1992): Wastewater treatment and use in agriculture. - FAO Irrig. \& Drain, paper No. 47. Roma.

[68] Plevich, O. J., Delgado, S. A. R., Saroff1, C., Tarico, J. C., Crespi, R.J., Barotto, O. M. (2012): El cultivo de alfalfa utilizando agua de perforación, agua residual urbana y precipitaciones. - Revista Brasileira de Engenharia Agrícola e Ambiental 16(12):1353-1358.

[69] Pilon-Smits, E. (2005): Phytoremediation. - Annual Review Plant Biology 56: 15-39.

[70] Post, J. (2006): Wastewater treatment and reuse in the eastern Mediterranean region. Water 21: 36-41.

[71] Ramírez-Zamora, R. M., Chávez-Mejía, A., Domínguez, M., Durán, M. A. (2004): Performance of basaltic dust issued from an asphaltic plant as a flocculant additive for wastewater treatment. - Water Science Technology 49(1): 147-154.

[72] Ramos, C. (1998): El uso de aguas residuales en riegos localizados y en cultivos hidropónicos. - Instituto Valenciano de Investigaciones Agrarias. Apdo. Oficial, 46113 Moncada, España.

[73] Rivera-Vázquez, R., Palacios-Vélez, O. L., Chávez Morales, J., Belmont, M. A., Nikolski-Gavrilov, I., De la Isla de Bauer Ma, de L., Guzmán-Quintero, A., TerrazasOnofre, L., Carrillo-González, R. (2007): Contaminación por coliformes y helmintos en los ríos Texcoco, Chapingo y San Bernardino tributarios de la parte oriental de la cuenca del Valle de México. - Revista Internacional de Contaminación Ambiental 23(2): 69-77.

[74] Rooney, C. P., Zhao, F. J., McGrath, S. P. (2006): Soil factors controlling the expression of copper toxicity to plants in a wide range of European soils. Environmental Toxicology Chemical 25: 726-732.

[75] Rulkens, W. (2008): Increasing significance of advanced physical/chemical processes in the development and application of sustainable wastewater treatment systems. Frontiers of Environmental Science \& Engineering, China 2:385-396.

[76] Sainz-Santamaría, J., Becerra Pérez, M. (2007): Los conflictos por agua en México: avances de investigación, http://www2.ine.gob.mx/publicaciones/gacetas/ 389/conf_agua.html.

[77] Sánchez-Viveros, G., Ferrera-Cerrato, R., Alarcón, A. (2013): Potencial del simbiosistema Azolla-Anabaena Azollae en la destoxificación de aguas contaminadas. In. Biorremediación de suelos y aguas, Alarcón A. and Ferrera-Cerrato R. Editores, Ed. Trillas, México, D.F. Pp235-256.

[78] Sarabia-Meléndez, I. F., Cisneros-Almazán, R., Aceves-De Alba, J., Durán-García, H. M., y Castro-Larragoitia, J. (2011): Calidad del agua de riego en suelos agrícolas y cultivos del Valle de San Luis Potosí, México. - Rev. Int. Contam. Ambient. 27(2):103-113.

[79] Shahabaldin, R., Ponraj, M., Talaiekhozani, A., Mohamad, S. E., Mohd, F. Md, D., Taib, S. M., Sabbagh, F., Sairan, F. Md. (2015): Perspectives of phytoremediation using water hyacinth for removal of heavy metals, organic and inorganic pollutants in wastewater. - Journal of Environmental Management 163(1): 125-133.

[80] SEMARNAT, NORMA Oficial Mexicana NOM-004-SEMARNAT-2002: Protección ambiental.- Lodos y biosólidos.-Especificaciones y límites máximos permisibles de contaminantes para su aprovechamiento y disposición final. - Secretaria de Medio Ambiente y Recursos Naturales, DOF. 15 de agosto de 2003, México.

[81] Siebe, C., Cifuentes, E. (1993): Environmental impact of wastewater irrigation in Central Mexico, an overview. -Inter. J. of Environmental Health Research 3(4):28

[82] Siebe, C. (1994): Acumulación y disponibilidad de metales pesados en suelos regados con aguas residuales en el distrito de riego 03, Tula, Hidalgo, México. - Revista 
Internacional de Contaminación Ambiental 10 (1): 15-21.

[83] Sierra, C. (2011): Calidad del Agua, evaluación y diagnóstico. - Universidad de Medellín, Colombia, 36.

[84] Silva, J., Torres, P., Madera, C. (2008): Reuso de aguas residuales domésticas en agricultura. Una revisión. - Agronomía Colombiana 26(2): 347-359.

[85] SINA. (2102): Atlas Digital del Agua México, Sistema Nacional de Información del Agua. - CONAGUA, Subdirección General de Programación, México, D.F.

[86] Tang, C., J. Cheng., Shindo S., Sakura, Y., Zhang, W., Shen, Y. (2004): Assessment of groundwater contamination by nitrate associated with wastewater irrigation: A case study in Shijrazhuang region, China. - Hydrological processes 18:2303 -2312.

[87] Tchobanoglous, G., Burton, L. F. (2005): Ingeniería de aguas residuales: tratamiento, vertido y reutilización. Metcalf y Eddy (Inc.). - Editorial McGraw Hill, College, New York, USA, 1819.

[88] Torres, C. J. (2009): Fitorremediación de aguas residuales por hidroponía. - Tesis de Maestría en Ciencias, Instituto Politécnico Nacional, D.F., México.

[89] Travieso, L., Sánchez, E., Borja, R., Benítez, F., León, M., Colmen-Arejo, M. F. (2004): Evaluation of a laboratory and full-scale microalgae pond for tertiary treatment of piggery waste. - Environmental Technology 25:565-576.

[90] Unnithan, V. (2014): Role of nannochloropsis for the recovery and persistence of MS2 virus in wastewater. - Algal Research 4(6): 70-75.

[91] Van-Hamme, J. D., Singh, A., Ward, O. P. (2003): Recent advances in petroleum microbiology. - Microbiology and Molecular Biology Reviews 67(4): 503-549.

[92] Vassilev, A., Schwitzguébel, J.P., Thewys, T., van der Lelie, P., Vangronsveld, J. (2004): The use of plants for remediation of metal-contaminated soils. - The Scientific World Journal 4:9-34.

[93] Westcott, D. W., Ayers, R. S. (1984): Water quality criteria, Chapter 3. Irrigation with Reclaimed Municipal Wastewater - A Guidance Manual. Report No. 84-1 WR California State Resources Control Board, Sacramento.

[94] WHO. (2006): Guidelines for the safe use of wastewater excreta and greywater. Wastewater use in agricultura.World Health Organization, Geneva 27, Switzerland, 2: $191 \mathrm{p}$.

[95] WSP. (2007): Saneamiento para el desarrollo, Cómo estamos en 21 países de América Latina y el Caribe. - Water and Sanitation Program, Banco Mundial, Agencia Suiza para el Desarrollo y la Cooperación (Cosud), Unicef y Banco Interamericano para el Desarrollo (Bid). Conferencia Latinoamericana de Saneamiento, Cali.

[96] Zerki, M., Koo, R. (1994): Treated municipal wastewater for citrus irrigation. Journal of Plant Nutrition 17:693-708. 